Website: http://www.adb.org

President: Haruhiko Kuroda (Japan).

\section{Asia-Pacific Economic Co-operation (APEC)}

Origin and Aims. APEC was originally established in 1989 to take advantage of the interdependence among Asia-Pacific economies, by facilitating economic growth for all participants and enhancing a sense of community in the region. Begun as an informal dialogue group, APEC is the premier forum for facilitating economic growth, co-operation, trade and investment in the Asia-Pacific region. APEC has a membership of 21 economic jurisdictions, a population of over $2.5 \mathrm{bn}$. and a combined GDP of US\$19trn. accounting for $47 \%$ of world trade.

APEC is working to achieve what are referred to as the 'Bogor Goals' of free and open trade and investment in the AsiaPacific by 2010 for developed economies and 2020 for developing economies.

Members. Australia, Brunei, Canada, Chile, China, Hong Kong, Indonesia, Japan, South Korea, Malaysia, Mexico, New Zealand, Papua New Guinea, Peru, Philippines, Russia, Singapore, Taiwan, Thailand, USA and Vietnam.

Activities. APEC works in three broad areas to meet the Bogor Goals. These three broad work areas, known as APEC's 'Three Pillars', are: Trade and Investment Liberalization-reducing and eliminating tariff and non-tariff barriers to trade and investment, and opening markets; Business Facilitation-reducing the costs of business transactions, improving access to trade information and bringing into line policy and business strategies to facilitate growth, and free and open trade; Economic and Technical Cooperation-assisting member economies build the necessary capacities to take advantage of global trade and the new economy. The 15th APEC Ministerial Meeting, held in Bangkok, Thailand in Oct. 2003, called for increased measures to stop the spread of terrorism and weapons of mass destruction.

Official language: English.

Headquarters: 35 Heng Mui Keng Terrace, Singapore 119616.

Website: http://www.apecsec.org.sg

Executive Director: Tran Trong Toan (Vietnam).

\section{Association of South East Asian Nations (ASEAN)}

History and Membership. ASEAN is a regional intergovernmental organization formed by the governments of Indonesia, Malaysia, the Philippines, Singapore and Thailand through the Bangkok Declaration which was signed by their foreign ministers on 8 Aug. 1967. Brunei joined in 1984, Vietnam in 1995, Laos and Myanmar in 1997 and Cambodia in 1999. Papua New Guinea also has observer status.

Objectives. The main objectives are to accelerate economic growth, social progress and cultural development, to promote active collaboration and mutual assistance in matters of common interest, to ensure the political and economic stability of the South East Asian region, and to maintain close co-operation with existing international and regional organizations with similar aims.
Activities. Principal projects concern economic co-operation and development, with the intensification of intra-ASEAN trade, and trade between the region and the rest of the world; joint research and technological programmes; co-operation in transportation and communications; promotion of tourism, South East Asian studies, cultural, scientific, educational and administrative exchanges. The decision to set up an ASEAN Free Trade Area (AFTA) was taken at the Fourth Summit meeting, in Singapore in 1992, with the aim of creating a common market in 15 years, subsequently brought forward to 2002. AFTA applies to its first six signatories, namely Brunei, Indonesia, Malaysia, Philippines, Singapore and Thailand. In 2003 ASEAN leaders signed a declaration to establish a free trade area by 2020.

In Dec. 1995 heads of government meeting in Bangkokestablished a South-East Asia Nuclear-Free Zone, which was extended to cover offshore economic exclusion zones. Individual signatories were to decide whether to allow port visits or transportation of nuclear weapons by foreign powers through territorial waters. The ASEAN Regional Forum (ARF) was proposed at a meeting of foreign ministers in July 1993 to discuss security issues in the region. Its first formal meeting took place in July 1994 attended by all seven members and its dialogue partners (Australia, Canada, the EU, Japan, South Korea, New Zealand and the USA) and observers (China, Laos, Papua New Guinea, Russia and Vietnam).

ASEAN is committed to resolving the dispute over sovereignty of the Spratly Islands, a group of more than 100 small islands and reefs in the South China Sea. Some or all of the largely uninhabited islands have been claimed by Brunei, China, Malaysia, the Philippines, Taiwan and Vietnam. The disputed areas have oil and gas resources.

Organization. The highest authority is the meeting of Heads of Government, which takes place annually. The highest policymaking body is the annual Meeting of Foreign Ministers, commonly known as AMM, the ASEAN Ministerial Meeting, which convenes in each of the member countries on a rotational basis in alphabetical order. The AEM (ASEAN Economic Meeting) meets each year to direct ASEAN economic cooperation. The AEM and AMM report jointly to the heads of government at summit meetings. Each capital has its own national secretariat. The central secretariat in Jakarta is headed by the Secretary-General, a post that revolves among the member states in alphabetical order every five years.

Official language: English.

Headquarters: POB 2072, Jakarta 12110, Indonesia.

Website: http://www.aseansec.org

Secretary-General: Ong Keng Yong (Singapore).

\section{ASEAN-Mekong Basin Development Co-operation (Mekong Group)}

The ministers and representatives of Brunei, Cambodia, China, Indonesia, Laos, Malaysia, Myanmar, Philippines, Singapore, Thailand and Vietnam met in Kuala Lumpur on 17 June 1996 and agreed the following basic objectives for the Group: to co-operate in the economic and social development of the Mekong Basin area and strengthen the link between it and ASEAN member countries, through a process of dialogue and common project identification.

Priorities include: development of infrastructure capacities in the fields of transport, telecommunications, irrigation and energy; development of trade and investment-generating activities; development of the agricultural sector to enhance production for domestic consumption and export; sustainable development of forestry resources and development of mineral resources; development of the industrial sector, especially small to medium enterprises; development of tourism; human resource development and support for training; co-operation in the fields of science and technology. 